\title{
Airborne bacteria in show caves from Southern Spain
}

\author{
Irene Dominguez-Moñino ${ }^{1}$, Valme Jurado ${ }^{1}$, Miguel Angel Rogerio-Candelera ${ }^{1}$, Bernardo Hermosin ${ }^{1}$ and \\ Cesareo Saiz-Jimenez ${ }^{1, *}$ \\ 1 Instituto de Recursos Naturales y Agrobiologia, IRNAS-CSIC, 41012 Sevilla, Spain. \\ * Corresponding Author: \\ Cesareo Saiz-Jimenez, Instituto de Recursos Naturales y Agrobiologia, IRNAS-CSIC, 41012 Sevilla, Spain; E-mail: saiz@irnase.csic.es
}

\begin{abstract}
This work presents a study on the airborne bacteria recorded in three Andalusian show caves, subjected to different managements. The main differences within the caves were the absence of lighting and phototrophic biofilms in Cueva de Ardales, the periodic maintenance and low occurrence of phototrophic biofilms in Gruta de las Maravillas, and the abundance of phototrophic biofilms in speleothems and walls in Cueva del Tesoro. These factors conditioned the diversity of bacteria in the caves and therefore there are large differences among the CFU $\mathrm{m}^{-3}$, determined using a suction impact collector, equipment widely used in aerobiological studies. The study of the bacterial diversity, inside and outside the caves, indicates that the air is mostly populated by bacteria thriving in the subterranean environment. In addition, the diversity seems to be related with the presence of abundant phototrophic biofilms, but not with the number of visitors received by each cave.
\end{abstract}

doi: 10.15698/mic2021.10.762

Received originally: 11.06.2021; In revised form: 13.07.2021,

Accepted 21.07.2021,

Published 26.07.2021.

Keywords: aerobiology, airborne bacteria, phototrophic biofilms, Bacillus, Arthrobacter, Micrococcus.

\section{INTRODUCTION}

The region of Andalusia, Southern Spain, has an important number of show caves and shelters, most of them containing Paleolithic art and with high cultural interest. Nerja, Tesoro, Piletas, Ardales and Murcielagos, are some representative caves with rock art, receiving different numbers of visitors and adopting distinct conservation and management protocols [1]. Other caves are visited by its geological interest and the occurrence of characteristic speleothems, such as Gruta de las Maravillas [2].

One of the management practices, not frequently adopted in cave conservation, is a periodic aerobiological monitoring. In fact, the major threat for a show cave is derived from the presence and colonization of microorganisms in the air, water pools, sediments and speleothems. This is particularly important when bacteria and fungi threat the paintings. A few and well-known examples can be found in Altamira [3-5] and Lascaux caves [6-8].

To help in the cave management of airborne fungi, Porca et al. [9] launched an ecological indicator that provides data on the amount of fungal spores and marks the limits of danger for the conservation of Paleolithic paintings. These authors categorized caves into five classes, from one without fungal problems to the worst case, a cave with irreversible ecological disturbance. The two last classes generally corresponded to caves experiencing fungal outbreaks, phototrophic biofilms resulting from artificial light- ing, or massive visits. The introduction of this ecological indicator was possible due to the well-characterized airborne fungal patterns, but unfortunately, this cannot be extended to bacteria. Indeed, bacteria do not present definite patterns in aerobiological studies, thus avoiding forecasting of bacterial outbreaks in caves. As a consequence, aerobiological studies should be adopted for each cave individually in order to measure airborne bacteria and adopt preventive conservation actions. The literature records several studies on bacteria in cave air [7, 10-16], but reports different conclusions.

The three show caves studied are located in Andalusia (Southern Spain) and were Cueva del Tesoro, Cueva de Ardales and Gruta de las Maravillas. Cueva del Tesoro and Cueva de Ardales contain valuable Paleolithic paintings and engravings, which can be observed by the visitors, while Gruta de las Maravillas, without paintings, holds rare speleothems. Comprehensive data on these caves were reported in a previous work investigating the aerobiological behavior of fungi [17]. The data previously reported include number of visitors at the sampling time, geomorphology and microclimatological data (temperature, concentration of carbon dioxide and radon) inside the caves. Briefly, in the sampling year the visits ranged from 130,314 peoples in Gruta de las Maravillas to 4,018 in Cueva de Ardales. Cueva del Tesoro received 28,257 visitors. Cave 

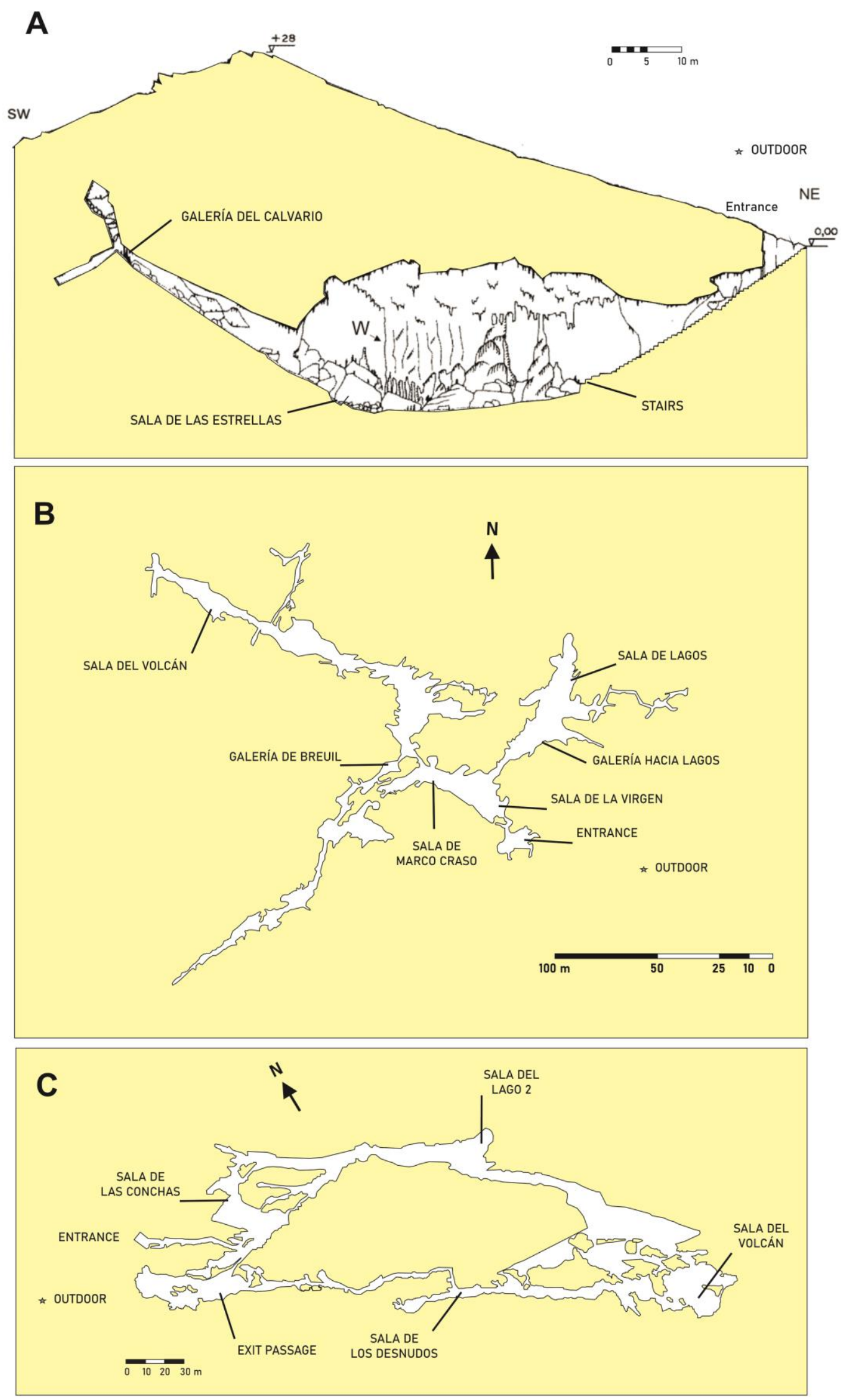

FIGURE 1: Map and sampling locations in the caves. (A) Cueva de Ardales; (B) Cueva del Tesoro; (C) Gruta de las Maravillas. 
lengths were from about 1,500 to $2,130 \mathrm{~m}$. Temperatures inside the caves ranged between $14.8^{\circ} \mathrm{C}$ and $17.4^{\circ} \mathrm{C}$ [17].

The main differences in the caves were the absence of lighting and phototrophic biofilms in Cueva de Ardales, the periodic maintenance and scarce occurrence of phototrophic biofilms in Gruta de las Maravillas, and the abundance of phototrophic biofilms in the speleothems and walls, in all the rooms and galleries, of Cueva del Tesoro. Cleaning and removal of biofilms were carried out in 2015, after this study [18].

In this paper we present an aerobiological study of three Andalusian show caves subjected to different managements. The caves cover examples from western to eastern Andalusia and are separated by more than $300 \mathrm{~km}$. Samplings were carried out along four seasons and the colony-forming units per cubic meter (CFU $\mathrm{m}^{-3}$ ) in different galleries and rooms were assessed (Figure 1).

\section{RESULTS}

There are large differences among the CFU $\mathrm{m}^{-3}$ in rooms and galleries, along the four seasons, in the three caves, as depicted in Figure $\mathbf{2}$ and Supplementary Tables S1-S12. The cave less frequented by visitors (Cueva de Ardales) presented the lowest amount of bacteria in the air, with a

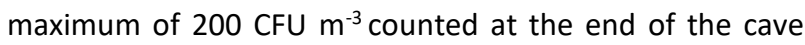
stair in spring, which was in agreement with the high quantity of bacteria outdoor $\left(320 \mathrm{CFU} \mathrm{\textrm {m } ^ { - 3 }}\right.$ ). Summer was the season with a lower amount of bacteria inside and outside the cave. Autumn and winter were the seasons with high and comparable airborne bacteria, both deepest in the cave and outside (180-110 CFU m $\mathrm{m}^{-3}$ ), as corresponded to a ventilation period. In this period, the air outside is colder and denser with respect to inside and enters into the cave transporting airborne bacteria.

41 different species were recorded inside this cave and 40 outside. Only eight of the bacteria recorded outside were also found inside the cave.

The most abundant bacteria identified inside Cueva de Ardales were Pseudarthrobacter spp. and Micrococcus luteus in spring; Bacillus altitudinis, Peribacillus simplex and Arthrobacter methylotrophus in summer; M. luteus in autumn; M. luteus and Arthrobacter citreus in winter. Outdoor, the most abundant bacteria were Pseudarthrobacter spp. in spring, and summer, Arthrobacter spp. in winter, and M. luteus in autumn (Supplementary Tables S1-S4).

In Cueva del Tesoro the higher CFU $\mathrm{m}^{-3}$ of bacteria were obtained in the air of Sala de la Virgen and Sala del Volcan (spring) and Galeria hacia Lagos and Galeria Breuil (summer), whereas the lower one was recorded outdoor. In spring and summer, the cave suffered a stagnation period, which explains the high rates of bacteria inside. This stagnation period is produced when the external temperature becomes higher than the cave temperature and the convective air circulation stops. In autumn and winter, the higher CFU mere obtained in Sala de la Virgen and Sala de Marco Craso, both next to the entrance, in agreement with the high number of bacteria outdoor. In these seasons, the entry of external cold air, typical of the ventilation pe- riod, has an enormous influence on the dispersal of outdoor airborne bacteria and their increase in the cave air. These stagnation and ventilation periods are common in caves.

In Cueva del Tesoro 130 different bacterial species were isolated from cave air and 34 outside, from which 17 were also recorded inside.

M. luteus was abundant in all the seasons, and Micrococcus endophyticus in spring and summer, but some other bacteria attained important abundances, such as Knoellia locipacati in spring and summer, and Streptomyces kurssanovii in autumn and winter. M. luteus was also abundant outdoor in spring, autumn and winter, whereas in summer Brevibacterium aurantiacum, Glutamicibacter spp. and Pseudarthrobacter psychrotolerans comprised about 63\% of the abundance (Supplementary Tables S5-S8).

Gruta de las Maravillas exhibited a high abundance of bacteria in a few rooms. The greater CFU $\mathrm{m}^{-3}$ were found in autumn (Sala de las Conchas and Exit Passage), although other rooms also displayed important CFU $\mathrm{m}^{-3}$ (Sala del Volcan, Sala del Lago 2). In most rooms, the CFU $\mathrm{m}^{-3}$ was twice the number of bacteria outdoor. In winter, the abundance of airborne bacteria inside decreased with respect to autumn between 7.5 and 1.5 times, but outdoor the bacteria increased 3 times. In the stagnation period (spring and summer) the amount of bacteria in the air varied considerably. The lower abundances were obtained in summer; the

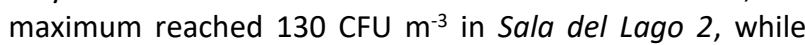

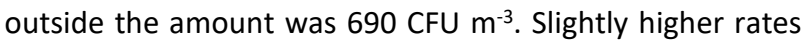
were recorded in spring (100-250 CFU m $\left.\mathrm{m}^{-3}\right)$, except for Sala

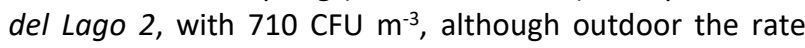
was the lowest ( $210 \mathrm{CFU} \mathrm{m}^{-3}$ ) of all the seasonal samplings. 94 species of bacteria were retrieved inside Gruta de las Maravillas and 48 outside, but only 18 of these were also isolated inside the cave.

Similar to Cueva del Tesoro, M. luteus and Micrococcus endophyticus were also the most abundant bacteria in Gruta de las Maravillas. Other relevant bacteria, including members of ten genera (Aerococcus, Bacillus, Brevundimonas, Staphylococcus, Kocuria, Corynebacterium, Empedobacter, Microbacterium, Agrococcus, Glutamicibacter) reached abundances above $20 \%$ in different rooms and seasons. Outside the cave a high diversity of bacteria was recorded of which $M$. luteus stood out (Supplementary Tables S9-S12).

\section{DISCUSSION}

The wide difference in bacterial diversity inside and outside the three caves supports the assumption that the air is mostly populated by bacteria specific to the subterranean environment. In fact, Cueva de Ardales and Gruta de las Maravillas showed a coincidence of 19.5 and $19.1 \%$, respectively, between inside and outside bacteria. Cueva del Tesoro only reached $12.6 \%$.

The diversity of bacterial species in the three caves seems to be related with the presence of abundant phototrophic biofilms. Thus, Cueva del Tesoro exhibited three times the bacterial species as Cueva de Ardales and represented about one and half of those found in Gruta de las 


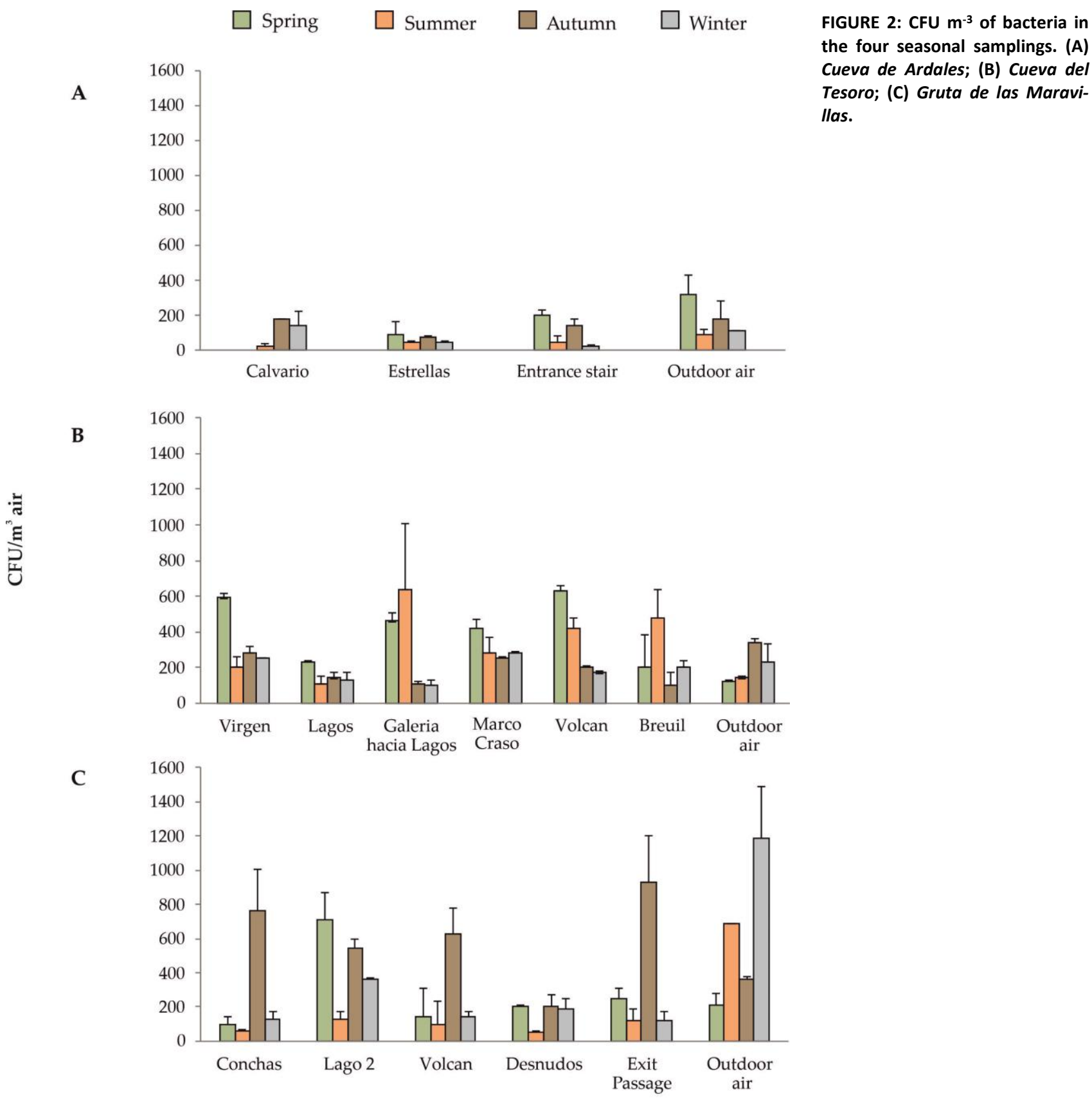

Sampling locations

Maravillas, which is in accordance with the extent of biofilms in each cave.

The high abundance of bacteria in Cueva del Tesoro can be explained by two facts: i) the narrow galleries and halls which prevent a dilution effect of bacteria in the air, and ii) the high density of phototrophic biofilms, all over the cave. On the contrary, Gruta de las Maravillas holds much bigger rooms with considerable volume (i.e. rooms with a height greater than $40 \mathrm{~m}$ ), and scarce phototrophic biofilms, which explains the reduced number of bacteria in the air. The low CFU $\mathrm{m}^{-3}$ of bacteria in Cueva de Ardales is consistent with the lack of phototrophic biofilms (no permanent lighting installation, and visited with pocket lamps), the high volume of the main hall (as seen in Figure 1A), and the low number of visitors.

The high amount of bacteria in Sala del Lago 2 in spring (710 CFU $\mathrm{m}^{-3}$ ) could be explained by the thermal zoning of the interior of Gruta de las Maravillas, which responds to various factors: morphology of the cave that influences the ventilation capacity, distance from the entrance (Figure 1C), influence of visitors, and the existence of a big lake and a few other small lakes. In fact, the lowest temperatures in the cave were recorded in Sala del Lago, with values between $15.7^{\circ} \mathrm{C}$ and $16.1^{\circ} \mathrm{C}$, which was attributed to a thermoregulatory effect of the lake's water mass [19]. This could stop the convective air circulation in Sala del Lago. 
The high bacterial diversity was not associated with the number of visitors received by each cave, which was almost 5 times higher in Gruta de las Maravillas than in Cueva del Tesoro. However, Cueva de Ardales was the cave with a lesser amount of bacterial species and visitors, in addition that no phototrophic biofilms were observed; these factors might explain the lower diversity.

The genus Micrococcus is the most characteristic and abundant in the three show caves. For instance, in Gruta de las Maravillas (Sala del Lago 2) the bacterium reached up to $92 \%$ of abundance in summer, in Cueva de Ardales the abundance was over $50 \%$ in all rooms in autumn, and Cueva del Tesoro presented similar quantities in four out of six sampling points in spring (Supplementary Tables S1S12).

This genus is commonly retrieved in European caves and the two most frequent species identified were Micrococcus yunnanensis and M. luteus [7, 20-23]. However, Huang et al. [24] proposed $M$. yunnanensis as later heterotypic synonym of $M$. luteus, based on the study of the whole-genome sequencing. In fact, both species are phenotypically and genotypically closely related and were differentiated by DNA-DNA hybridization, although for operative purposes were distinguished by their 16S rRNA sequences and the oxidase test, negative for $M$. yunnanensis and positive for M. luteus. Huang et al. [24], in addition to the reclassification as a single species, further considered M. luteus as oxidase-variable.

The wide distribution of $M$. yunnanensis in caves relies on the ability to grow at temperature as low as $4{ }^{\circ} \mathrm{C}$ (with an optimal growth temperature of $28^{\circ} \mathrm{C}$ ), while $M$. luteus requires higher temperatures and the optimal growth temperature is $37^{\circ} \mathrm{C}$. In their reclassification of Micrococcus species, Huang et al. [24] extended the temperature range of $M$. luteus from 4 to $45^{\circ} \mathrm{C}$.

M. yunnanensis was retrieved from European caves [7, $22,25]$ and $M$. luteus was recorded in European, Asian and African caves [26-28].

After $M$. luteus, $M$. endophyticus occupies the second rank in abundance in the three caves. This species was isolated from plant roots [29] and, as far as we know, was not previously reported in caves. Their presence in the air of three different caves supports an adaptation to subterranean niches, as suggested by the high CFU in the deepest galleries and their practical absence outside the cave.

Other less frequent Micrococci were Micrococcus terreus (present in the three caves) and Micrococcus antarcticus (in Cueva del Tesoro and Gruta de las Maravillas). Whereas $M$. terreus was isolated from different caves [13, 22], $M$. antarcticus was previously found in a coastal cave [13]. The optimum temperature for growth of this bacterium was $16.8^{\circ} \mathrm{C}$, which agrees with the temperatures of the caves [17].

Many species of the genus Arthrobacter were recently transferred to other genera: Pseudarthrobacter, Glutamicibacter or Paenarthrobacter [30]. The genera Pseudarthrobacter, Glutamicibacter, and Arthrobacter were the second most abundant in the caves. Contrary to the low number of Micrococcus species in the caves, for these four genera 28 different species were recorded from which nine species were not retrieved inside (Supplementary Tables S1-S12). Seven species ( $P$. phenanthrenivorans, Pseudarthrobacter oxydans, A. methylotrophus, A. citreus, Glutamicibacter mysorens, Glutamicibacter nicotianae and Glutamicibacter arilaitensis) were found with abundances over $20 \%$ in the three caves. A few species were previously recorded in caves, such as $A$. methylotrophus, isolated from the air in the stair of Cueva de Ardales [11], and from the same place in this study, or Glutamicibacter arilaitensis in Lascaux Cave [7].

Furthermore, sequences with $98 \%$ similarity for $P$. oxydans were retrieved from an oligotrophic cave [31]. However, as far as we known, other Arthrobacter were not isolated from caves but from contaminated soils [32, 33].

The third most frequent genus was Bacillus, although the first in terms of biodiversity. 21 species of this genus were retrieved, 16 inside the cave and five more outside, but only four (B. altitudinis, Bacillus idriensis, Bacillus aryabhattai and Bacillus vietnamensis) attained abundances above $20 \%$ in any of the caves. Of interest was the identification of a new species: Bacillus onubensis. Two strains isolated from the air of Cueva del Tesoro and Gruta de las Maravillas were previously used for the description of this species [34]. Another new species, Paracoccus cavernae, was isolated from Cueva de Ardales [35].

Bacillus is one of the most abundant genus in caves all over the world [10, 11, 14, 36, 37]. Lavoie and Northup [38] correlated the presence of Bacillus in caves with high visitation levels, and Jurado et al. [39] associated this genus with the abundance of phototrophic biofilms. This is in aggreement with the presence of eleven different species in Cueva del Tesoro, seven in Gruta de las Maravillas and three in Cueva de Ardales, showing a direct relationship with the abundance of biofilms in each cave.

In addition, twelve bacterial genera related with the genus Bacillus were isolated from the caves: Brevibacillus, Cytobacillus, Mesobacillus, Metabacillus, Neobacillus, Lysinibacillus, Paenibacillus, Peribacillus, Psychrobacillus, Solibacillus, Ureibacillus and Terribacillus, although most of the members of these genera were recovered with abundances below 5\%, except Peribacillus simplex (50\%), Paenibacillus amylolyticus (10-12\%), and Lysinibacillus odyssey (9.8\%) in Cueva del Tesoro, and Terribacillus goriensis (8\%) in Gruta de las Maravillas (Supplementary Tables S1-S12).

Streptomyces is one of the most abundant genus in caves, irrespective of the geographical situation [19, 40-44]. 22 species were recorded in this study, from which three (Streptomyces lateritius, Streptomyces daghestanicus, Streptomyces spinoverrucosus) were not found inside the caves. The number of species retrieved from the three caves showed a correlation with the abundance of biofilms as well (eleven in Cueva del Tesoro, five in Gruta de las Maravillas and three in Cueva de Ardales). Apart from $S$. kurssanovii that reached abundances as high as $60 \%$, only five more species (Streptomyces exfoliatus, Streptomyces anulatus, Streptomyces rochei, Streptomyces longisporoflavus, Streptomyces xantholiticus) slightly surpassed $10 \%$ in Cueva del Tesoro; the remaining were well below $10 \%$ in all 
the three caves. Most of these six Streptomyces were found in other caves [21, 45-48].

Other abundant bacteria (over 20\%) in the studied caves were Terrabacter terrigena, Variovorax boronicumulans, Phyllobacterium ifriqiyense, Lentzea albidocapillata subsp. albidocapillata, K. locipacati, Knoellia subterranea, Jeotgalicoccus halophilus, Serratia liquefaciens, Sporosarcina luteola, Microbacterium esteraromaticum, Bhargavaea cecembensis, Aerococcus urinaeequi, Brevundimonas vesicularis/B. nasdae, Staphylococcus haemolyticus, Kocuria palustris, Staphylococcus saprophyticus subsp. bovis, Corynebacterium glutamicum, Empedobacter brevis, Microbacterium lacus, and Agrococcus baldri. Most of these genera were reported in caves, but not all the species found in the three caves were previously recorded in similar environments [7, 13, 21, 49-52]. Interestingly, a few of these genera provided new species isolated from subterranean niches [53, 54], particularly $K$. subterranea, which reached $73.2 \%$ in Cueva del Tesoro. This bacterium was isolated and described from a Chinese cave [55]. The data indicate that caves are reservoirs for novel species of bacteria [34, 35, 54-56] as shown by the isolation of a novel Paracoccus onubensis from the walls of Gruta de las Maravillas [57].

To summarize, phototrophic biofilms seem to be the cause of the elevated abundance and diversity of bacteria in the caves and, at the same time, represent a danger for the conservation of the Paleolithic art and speleothems.

\section{CONCLUSION}

In cultural heritage studies, a preventive conservation protocol includes the need to achieve aerobiological analysis for assessing the biological risk and to propose strategies aimed at controlling biodeterioration.

Aerobiology has proven to be a suitable approach for studying the dispersion of airborne bacteria in caves and to forecast the risks of eventual colonization of speleothems, walls and, subsequently, the biodeterioration of rock art.

The aerobiological study of three Andalusian caves shows large differences in CFU $\mathrm{m}^{-3}$ in rooms and galleries, along the four seasons of the year. These differences were related to the presence or absence of lighting and phototrophic biofilms and conditioned the diversity of bacteria in the caves. The diversity seems to be related with the abundant phototrophic biofilms, but not clearly associated with the number of visitors. The data show that the presence of phototrophic biofilms enhances the amount of bacteria in the air and the threat for the paintings and engravings. In addition, bacterial diversity data, inside and outside the three caves support that the cave air is mostly populated by species characteristic for the subterranean environment.

The data clearly indicate that phototrophic biofilms have to be removed, and the speleothems and walls cleaned. This should be accompanied by the use of a friendly illumination system to avoid the growth of cyanobacteria and algae, in order to protect the rock art.

\section{MATERIALS AND METHODS}

Four aerobiological sampling campaigns were carried out between May 2011 and March 2012. In each cave campaign a representative number of galleries and/or rooms and an outdoor sampling point as control were selected, as indicated in Figure 1 and Supplementary Tables S1-S12.

The methodology used was exhaustively described [4, 7]. A Surface Air System (Duo SAS, model Super 360) was used in the sampling [7]. Samples were taken in duplicates, at each sampling point and the volume of filtered air was set to 100 liters. This volume was selected because at higher volumes, colony-forming units per cubic meter (CFU m-3) were too high for counting [9]. The culture medium was trypticase-soy-agar (TSA, BD) with addition of cycloheximide $(50 \mu \mathrm{g} / \mathrm{mL}$; Applichem, Darmstad, Germany).

Counting and isolation of bacteria were accomplished for each colony type, using as selection criteria morphological characters. The bacteria were isolated in TSA culture medium.

The amounts of bacteria in each air sample were expressed as CFU $\mathrm{m}^{-3}$. The number of colonies counted was corrected for the statistical possibility of multiple particles passing through the same hole, following manufacturer's instructions.

Bacterial DNA was extracted and PCR products were sent to Macrogen Inc. (Amsterdam, The Netherlands) for sequencing. Molecular protocols and data were previously reported [7]. Briefly, DNA was extracted by dispersing a bacterial colony in $100 \mu \mathrm{l}$ of $10 \mathrm{mM}$ TNE buffer, and freeze-thawing at $-80^{\circ} \mathrm{C}$ and $65^{\circ} \mathrm{C}$, respectively. For $16 \mathrm{~S}$ rRNA amplification, the primers 616F (5'-AGAGTTTGATYMTGGCTCAG-3') [58] and 1510R (5'-GGTTACCTTGTTACGACTT-3' [59] were used. PCR amplifications were performed in a BioRad iCycler thermal cycler (BioRad, Hercules, CA, USA) using the following cycling parameters: 2 min of initial denaturing step at $95^{\circ} \mathrm{C}$, followed by 35 cycles of denaturing $\left(95^{\circ} \mathrm{C}\right.$ for $\left.1 \mathrm{~min}\right)$, annealing $\left(55^{\circ} \mathrm{C}\right.$ for 1 $\mathrm{min}$ ) and extension $\left(72^{\circ} \mathrm{C}\right.$ for $\left.2 \mathrm{~min}\right)$, with an additional extension step at $72^{\circ} \mathrm{C}$ for $10 \mathrm{~min}$ at the end.

For phylogenetic identification, the sequences were compared, using BLASTn algorithm, to the non-redundant databases of sequences deposited at the National Center for Biotechnology Information (NCBI). The sequences were deposited into the GenBank database under accession numbers MZ338588- MZ339147, LN650666, LN650668 and LN774332.

\section{AUTHOR CONTRIBUTION}

Conceptualization, C.S.-J.; investigation, I.D-M; V.J.; M.A.RC.; B.H.; writing-original draft preparation, C.S.-J.; writing-review and editing, C.S.-J.; All authors reviewed the results and approved the final version of the manuscript.

\section{ACKNOWLEDGEMENTS}

This research was funded by Junta de Andalucia, grant number RNM-5137. I.D-M acknowledges the pre-doctoral grant associated to project RNM-5137. The authors wish to acknowledge the professional support of the CSIC Interdisciplinary Thematic Platform Open Heritage: Research and Society (PTI-PAIS), as well as the facilities of the cave administrators for sampling. 


\section{SUPPLEMENTAL MATERIAL}

All supplemental data for this article are available online at www.microbialcell.com.

\section{CONFLICT OF INTEREST}

The authors declare no conflict of interest.

\section{COPYRIGHT}

(C) 2021 Dominguez-Moñino et al. This is an open-access article released under the terms of the Creative Commons

\section{REFERENCES}

1. Fernández-Cortés A, Calaforra JM, Martín-Rosales W, González-Ríos MJ (2008). Cavidades turísticas de Andalucía. In: Calaforra Chordi JM, Berrocal Pérez JA, editors. El Karst de Andalucía. Geoespeleología, Bioespeleología y Presencia Humana. Consejería de Medio Ambiente, Junta de Andalucía, Sevilla; pp 105-115.

2. Martín-Rosales W, López-Chicano M, Calaforra JM, Lauritzen SE, Sáez F, Rodríguez CM (2008). La Gruta de las Maravillas. In: Calaforra Chordi JM, Berrocal Pérez JA, editors. El Karst de Andalucía. Geoespeleología, Bioespeleología y Presencia Humana. Consejería de Medio Ambiente, Junta de Andalucía, Sevilla; pp 209-215.

3. Saiz-Jimenez C, Cuezva S, Jurado V, Fernandez-Cortes A, Porca E, Benavente D, Cañaveras JC, Sanchez-Moral S (2011). Paleolithic art in peril: policy and science collide at Altamira Cave. Science 334: 42-43. doi: $10.1126 /$ science. 1206788

4. Garcia-Anton E, Cuezva S, Jurado V, Porca E, Miller AZ, FernandezCortes A, Saiz-Jimenez C, Sanchez-Moral S (2014). Combining stable isotope $\left(\delta^{13} \mathrm{C}\right)$ of trace gases and aerobiological data to monitor the entry and dispersion of microorganisms in caves. Environ Sci Pollut Res 21: 473-484. doi: 10.1007/s11356-013-1915-3

5. Cuezva S, Jurado V, Fernandez-Cortes A, Garcia-Anton E, RogerioCandelera MA, Ariño X, Benavente D, Cañaveras JC, Saiz-Jimenez C, Sanchez-Moral S (2015). Scientific data suggest Altamira Cave should remain closed. In: Engel AS, editor. Microbial Life of Cave Systems. DeGruiter, Berlin; pp 303-320.

6. Martin-Sanchez PM, Nováková A, Bastian F, Alabouvette C, SaizJimenez $C$ (2012). Use of biocides for the control of fungal outbreaks in subterranean environments: The case of the Lascaux Cave in France. Environ Sci Technol 46: 3762-3770. doi: 10.1021/es2040625

7. Martin-Sanchez PM, Jurado V, Porca E, Bastian F, Lacanette D, Alabouvette C, Saiz-Jimenez C (2014). Airborne microorganisms in Lascaux Cave (France). Int J Speleol 43: 295-303. doi: 10.5038/1827806X.43.3.6

8. Martin-Sanchez P, Miller AZ, Saiz-Jimenez C (2015). Lascaux Cave: An example of fragile ecological balance in subterranean environments. In: Engel AS, editor. Microbial Life of Cave Systems. DeGruiter, Berlin; pp 280-301.

9. Porca E, Jurado V, Martin-Sanchez P, Hermosin B, Bastian F, Alabouvette C, Saiz-Jimenez, C (2011). Aerobiology: An ecological indicator for early detection and control of fungal outbreaks in caves. Ecol Indic 11: 1594-1598. doi: 10.1016/j.ecolind.2011.04.003

10. Wang W, Ma Y, Ma X, Wu F, Ma X, An L, Feng H. (2012). Diversity and seasonal dynamics of airborne bacteria in the Mogao Grottoes, Dunhuang, China. Aerobiologia 28: 27-38. doi: 10.1007/s10453-0119208-0

11. Fernandez-Cortes A, Cuezva S, Sanchez-Moral S, Porca E, Jurado V, Saiz-Jimenez C (2011). Detection of human-induced environmental disturbances in a show cave. Environ Sci Pollut Res 18: 1037-1045. doi: 10.1007/s11356-011-0513-5
Attribution (CC BY) license, which allows the unrestricted use, distribution, and reproduction in any medium, provided the original author and source are acknowledged.

Please cite this article as: Irene Dominguez-Moñino, Valme Jurado, Miguel Angel Rogerio-Candelera, Bernardo Hermosin and Cesareo Saiz-Jimenez (2021). Airborne bacteria in show caves from Southern Spain. Microbial Cell 8(10): 247-255. doi: 10.15698/mic2021.10.762

12. Mulec J, Vaupotic J, Walochnik J (2012). Prokaryotic and eukaryotic airborne microorganisms as tracers of microclimatic changes in the underground (Postojna Cave, Slovenia). Microb Ecol 64: 654-667. doi: 10.1007/s00248-012-0059-1

13. Mulec J, Oarga-Mulec A, Sturm S, Tomazin R, Matos T (2017). Spacio-temporal distribution and tourist impact on airborne bacteria in a cave (Škocjan Caves, Slovenia). Diversity 9: 28. doi:10.3390/d9030028

14. Ma $Y$, Zhang $H$, Du $Y$, Tian $T$, Xiang $T$, Liu X-D, Wu F, An L, Wang W, $\mathrm{Gu} J-D$, Feng $H$ (2015). The community distribution of bacteria and fungi on ancient wall paintings of the Mogao Grottoes. Sci Rep 5: 7752. doi: $10.1038 /$ srep07752

15. Bercea S, Nastase-Bucur R, Moldovan OT, Kenesz M, Constantin S (2019). Yearly microbial cycle of human exposed surfaces in show caves. Subterr Biol 31: 1-14. doi: 10.3897/subtbiol.31.34490

16. Wojkowski, J., Andreychouk, V., Frączek, K. (2019). Airborne microorganisms of hypogenic maze caves based on the example of the Zoloushka Cave, Ukraine-Moldova. Rocz Ochr Środowiska 21: 11161135. ISSN 1506-218X.

17. Dominguez-Moñino I, Jurado V, Rogerio-Candelera MA, Hermosin B, Saiz-Jimenez C (2021). Airborne fungi in show caves from Southern Spain Appl Sci 11: 5027. doi: 10.3390/app11115027

18. Jurado $V$, Hernández-Mariné $M$, Rogerio-Candelera MA, Domínguez-Moñino I, Gutiérrez-Patricio S, Sáiz-Jiménez C (2014). La Cueva del Tesoro: un paraíso microbiano. In: Calaforra JM, Durán JJ, editors. Cuevatur 2014/Iberoamérica Subterránea; ACTE, Madrid; pp 431-439.

19. Martín-Rosales W, Cerón JC, López-Chicano M, Fernández I (2003). Aspectos ambientales e hidrogeológicos de la Gruta de las Maravillas (Huelva, España). Bol Geol Min 114: 247-254.

20. Urzì C, De Leo F, Bruno L, Albertano $P$ (2010). Microbial diversity in paleolithic caves: a study case on the phototrophic biofilms of the Cave of Bats (Zuheros, Spain). Microb Ecol 60: 116-129. doi: 10.1007/s00248010-9710-x

21. Tomova I, Lazarkevich I, Tomova A, Kambourova M VasilevaTonkova E (2013). Diversity and biosynthetic potential of culturable aerobic heterotrophic bacteria isolated from Magura Cave, Bulgaria. Int J Speleol 42: 65-76. doi:10.5038/1827-806X.42.1.8

22. Busquets A, Fornós JJ, Zafra F, Lalucat J, Merino A (2014). Microbial communities in a coastal cave: Cova des Pas de Vallgornera (Mallorca, Western Mediterranean). Int J Speleol 43: 205-216. doi:10.5038/1827-806X.43.2.8

23. Herzog Velikonja B, Tkavc R, Pašić L (2014). Diversity of cultivable bacteria involved in the formation of microbial colonies (cave silver) on the walls of a cave in Slovenia. Int J Speleol 43: 45-56. doi: 10.5038/1827-806X.43.1.5 
24. Huang C-H, Wang C-L, Lio, J-S, Lee A-Y, Blom J, Huang L, Watanabe $\mathrm{K}$ (2019). Reclassification of Micrococcus aloeverae and Micrococcus yunnanensis as later heterotypic synonyms of Micrococcus luteus. Int J Syst Evol Microbiol 69: 3512-3518. doi: 10.1099/ijsem.0.003654

25. Anda D, Krett G, Makk J, Márialigeti K, Mádl-Szőnyi J, Borsodi AK (2017). Comparison of bacterial and archaeal communities from different habitats of the hypogenic Molnár János Cave of the Buda Thermal Karst System (Hungary). J Cave Karst Stud 79: 113-121. doi: 10.4311/2015MB0134

26. Jurado V, Laiz L, Sanchez-Moral S, Saiz-Jimenez C (2014). Pathogenic microorganisms related to human visits in Altamira Cave, Spain. In: Saiz-Jimenez C, editor. The Conservation of Subterranean Cultural Heritage, Taylor and Francis, London; pp 229-238.

27. Belyagoubi L, Belyagoubi-Benhammou N, Jurado V, Dupont J, Lacoste S, Djebbah F, Ounadjela FZ, Benaissa S, Habi S, Abdelouahi DE, Saiz-Jimenez C (2018). Antimicrobial activities of culturable microorganisms (actinomycetes and fungi) isolated from Chaabe Cave, Algeria. Int J Speleol 47: 189-199. doi: 10.5038/1827-806X.47.2.2148

28. Hamedi J, Kafshnouchi M, Ran M (2019). A study on actinobacterial diversity of Hampoeil cave and screening of their biological activities. Saudi J Biol Sci 26: 1587-1595. doi: 10.1016/j.sjbs.2018.10.010

29. Chen H-H, Zhao G-Z, Park D-J, Zhang Y-Q, Xu L-H, Lee J-C, Kim C-J, Li W-J (2009). Micrococcus endophyticus sp. nov., isolated from surfacesterilized Aquilaria sinensis roots. Int J Syst Evol Microbiol 59: 10701075. doi: 10.1099/ijs.0.006296-0

30. Busse H-J (2016). Review of the taxonomy of the genus Arthrobacter, emendation of the genus Arthrobacter sensu lato, proposal to reclassify selected species of the genus Arthrobacter in the novel genera Glutamicibacter gen. nov., Paeniglutamicibacter gen. nov., Pseudoglutamicibacter gen. nov., Paenarthrobacter gen. nov. and Pseudarthrobacter gen. nov., and emended description of Arthrobacter roseus. Int J Syst Evol Microbiol 66: 9-37. doi:10.1099/ijsem.0.000702

31. Barton HA, Taylor MR, Pace NR (2004). Molecular phylogenetic analysis of a bacterial community in an oligotrophic cave environment. Geomicrobiol J 21: 11-20. doi: 10.1080/01490450490253428

32. Karigar C, Mahesh A, Nagenahalli M, Yun DJ (2006). Phenol degradation by immobilized cells of Arthrobacter citreus. Biodegradation 17: 47-55. doi: 10.1007/s10532-005-3048-y

33. Kallimanis A, Kavakiotis K, Perisynakis A, Spröer C, Pukall R, Drainas C, Koukkou Al (2009). Arthrobacter phenanthrenivorans sp. nov., to accommodate the phenanthrene-degrading bacterium Arthrobacter sp. strain Sphe3. Int J Syst Evol Microbiol 59: 275-279. doi: 10.1099/ijs.0.000984-0

34. Dominguez-Moñino I, Jurado V, Gonzalez-Pimentel JL, Miller AZ, Hermosin B, Saiz-Jimenez C (2018). Bacillus onubensis sp. nov., isolated from the air of two Andalusian caves. Syst Appl Microbiol 41: 167-172. doi: 10.1016/j.syapm.2018.01.001

35. Dominguez-Moñino I, Jurado V, Hermosin B, Saiz-Jimenez C (2016) Paracoccus cavernae sp. nov., isolated from a show cave. Int J Syst Evol Microbiol 66: 1-6. doi: 10.1099/ijsem.0.001018

36. Adetutu EM, Thorpe K, Shahsavari E, Bourne S, Cao X, Fard RMN, Kirby G, Ball AS (2012). Bacterial community survey of sediments at Naracoorte Caves, Australia. Int J Speleol 41: 137-147. doi: 10.5038/1827-806X.41.2.2

37. Mitova M, Iliev M, Groudeva V (2015). Identification of Bacillus strains isolated from rock paintings in Magoura cave, Bulgaria. J BioSci Biotechnol 2015: 303-306. ISSN: 1314-6246.

38. Lavoie KH, Northup DE (2005). Bacteria as indicators of human impact in caves. 2005 National Cave and Karst Management Symposium, pp 40-47.
39. Jurado V, del Rosal, Y, Gonzalez-Pimentel JL, Hermosin B, Saiz-Jimenez $C$ (2020). Biological control of phototrophic biofilms in a show cave: The case of Nerja Cave. Appl Sci 10: 3448. doi: 10.3390/app10103448

40. Groth I, Vetermann R, Schuetze B, Schumann P, Saiz-Jimenez C (1999). Actinomycetes in kartic caves of Northern Spain (Altamira and Tito Bustillo). J Microbiol Methods 36: 115-122. doi: 10.1016/s01677012(99)00016-0

41. Groth I, Schumann P, Laiz L, Sanchez-Moral S, Cañaveras JC, SaizJimenez C (2001). Geomicrobiological study of the Grotta dei Cervi, Porto Badisco, Italy. Geomicrobiol J 18: 241-258. doi: 10.1080/01490450152467778

42. Maciejewska $M$, Adam D, Naômé A, Martinet L, Tenconi $E$, Całusinska $M$, Delfosse $P$, Hanikenne $M$, Baurain $D$, Compère $P$, Carnol $M$, Barton HA, Rigali S (2017). Assessment of the potential role of Streptomyces in cave moonmilk formation. Front Microbiol 8: 1181 doi: 10.3389/fmicb.2017.01181

43. Gonzalez-Pimentel JL, Jurado V, Hermosin B, Saiz-Jimenez C (2020). Draft genome sequences of two Streptomyces strains, MZ03-37T and MZ03-48, isolated from lava tube speleothems. Microbiol Resour Announc 9: e00576-20. 10.1128/MRA.00576-20

44. Martin-Pozas T, Sanchez-Moral S, Cuezva S, Jurado J, Saiz-Jimenez C, Perez-Lopez R, Carrey R, Otero N, Giesemann A, Well R, Calaforra JM, Fernandez-Cortes A (2020). Biologically mediated release of endogenous $\mathrm{N}_{2} \mathrm{O}$ and $\mathrm{NO}_{2}$ gases in a hydrothermal, hypoxic subterranean environment. Sci Total Environ 747: 141218. doi: 10.1016/j.scitotenv.2020.141218

45. Rajput Y, Biswas J, Rai V (2012). Potentiality test in antimicrobial activity and antibiotic sensitivity of subterranean Streptomyces strains isolated from Kotumsar Cave of India. Int J Biol Chem 6: 53-60. doi: 10.3923/ijbc. 2012.53 .60

46. Voytsekhovskaya IV, Axenov-Gribanov DV, Murzina SA, Pekkoeva SN, Protasov ES, Gamaiunov SV, Timofeyev MA (2018). Estimation of antimicrobial activities and fatty acid composition of actinobacteria isolated from water surface of underground lakes from Badzheyskaya and Okhotnichya caves in Siberia. PeerJ 6: e5832. doi: 10.7717/peerj.5832

47. Gonzalez-Pimentel JL (2019). Microorganismos de las cuevas volcánicas de La Palma (Islas Canarias): Diversidad y potencial uso biotecnológico. Ph D Thesis. Universidad Pablo de Olavide, Sevilla.

48. Al-Ghamdi SA, Jastaniah SD, Amasha RH (2021). Isolation and screening of actinomycetes from Umm Jirsan Cave, Saudi Arabia for their antibacterial activity. Biosc Biotech Res Comm 14 (1). doi: $10.21786 / \mathrm{bbrc} / 14.1 / 50$.

49. Laiz L, Groth I, Gonzalez I, Saiz-Jimenez C (1999). Microbiological study of the dripping waters in Altamira cave (Santillana del Mar, Spain). J Microbiol Methods 36: 129-138. doi: 10.1016/s01677012(99)00018-4

50. Campbell JW, Watson A, Watson C, Ball H, Pirkle R (2011). Escherichia coli, other coliforms, and environmental chemoheterotrophic bacteria in isolated water pools from six caves in northern Alabama and northwestern Georgia. J Cave Karst Stud 73: 75-82. doi: 10.4311/jcks2009mb0131

51. Omoregie Al, Senian N, Li PY, Hei NL, Leong DOE, Ginjom IRH, Nisson PM (2016). Ureolytic bacteria isolated from Sarawak limestone caves show high urease enzyme activity comparable to that of Sporosarcina pasteurii (DSM 33). Malays J Microbiol 12: 463-470. ISSN 2231-7538.

52. Duncan TR (2017). Bacterial siderophore production in Lechuguilla and Spider Caves, Carlsbad National Park (CCNP) Carlsbad, New Mexico. Ph D Thesis, University of New Mexico, Albuquerque. Available at: 
https://digitalrepository.unm.edu/biol_etds/251.

[Accessed: 28.01.2021]

53. Jurado V, Laiz L, Gonzalez JM, Portillo MC, Hernandez-Marine M, Saiz-Jimenez C (2005). Phyllobacterium catacumbae, sp. nov., a Rhizobiaceae isolated from Roman catacombs. Int J Syst Evol Microbiol 55: 1487-1490. doi: 10.1099/ijs.0.63402-0

54. Fang B-Z, Han M-X, Liu L, Zhan Z-T, Liu W-L, Shen J-T, Wang Y, Zhan W-Q, Wei D-Q, Li W-J (2017). Lentzea cavernae sp. nov., an actinobacterium isolated from a karst cave sample, and emended description of the genus Lentzea. Int J Syst Evol Microbiol 67: 2357-2362. doi: 10.1099/ijsem.0.001958

55. Groth I, Schumann P, Schütze B, Augsten K, Stackebrandt E (2002). Knoellia sinensis gen. nov., sp. nov. and Knoellia subterranea sp. nov., two novel actinobacteria isolated from a cave. Int J Syst Evol Microbiol 52: 77-84. doi: 10.1099/00207713-52-1-77
56. Jurado V, Laiz L, Rodriguez-Nava V, Boiron P, Hermosin B, SanchezMoral S, Saiz-Jimenez C (2010). Pathogenic and opportunistic microorganisms in caves. Int J Speleol 39: 15-24. doi: 10.5038/1827806x.39.1.2

57. Gutierrez-Patricio S, Gonzalez-Pimentel JL, Miller AZ, Hermosin B, Saiz-Jimenez C (2021) Paracoccus onubensis sp. nov., a novel alphaproteobacterium isolated from the wall of a show cave. Int J Syst Evol Microbiol. doi: 10.1099/ijsem.0.004942.

58. Snaidr J, Amann R, Huber I, Ludwig W, Schleifer K-H (1997) Phylogenetic analysis and in situ identification of bacteria in activated sludge. Appl Environ Microbiol 63: 2884-2896. doi: 10.1128/aem.63.7.2884-2896.1997

59. Lane DJ (1991) 16S/23S rRNA sequencing. In: Stackenbrandt E, Goodfellow M, editors. Nucleic acid techniques in bacterial systematic. John Wiley, Chichester; pp. 115-175. 